\title{
Optimizing Plant Spacing under the Systems of Rice Intensification (SRI)
}

\author{
Paul Reuben ${ }^{*}$, Fredrick C. Kahimba1, Zacharia Katambara², Henry F. Mahoo1, \\ Winfred Mbungu' ${ }^{1}$, Fikiri Mhenga ${ }^{1}$, Anthony Nyarubamba ${ }^{3}$, Muyenjwa Maugo ${ }^{3}$ \\ ${ }^{1}$ Department of Agricultural Engineering and Land Planning, Sokoine University of Agriculture (SUA), Morogoro, \\ Tanzania \\ ${ }^{2}$ Department of Built Environment Engineering, Mbeya University of Science and Technology (MUST), Mbeya, \\ Tanzania \\ ${ }^{3}$ Ministries of Agriculture, Food Security (MAFC), Dar es Salaam, Tanzania \\ Email: *reubenpal@gmail.com, *reubenpal@suanet.ac.tz
}

Received 29 March 2016; accepted 23 April 2016; published 27 April 2016

Copyright (C) 2016 by authors and Scientific Research Publishing Inc.

This work is licensed under the Creative Commons Attribution International License (CC BY).

http://creativecommons.org/licenses/by/4.0/

(c) (i) Open Access

\section{Abstract}

Optimum plant spacing is among key agronomic parameters that influence crop growth performance and crop yield. A study was conducted to investigate the optimum rice transplanting spacing under the Systems of Rice Intensification (SRI) practice in Tanzania. The study composed of five treatments of rice transplanting spacing namely 1) $15 \mathrm{~cm} \times 15 \mathrm{~cm}$ (T1); 2) $20 \mathrm{~cm} \times 20 \mathrm{~cm}(\mathrm{~T} 2)$; 3) $25 \mathrm{~cm} \times 25 \mathrm{~cm}$ (T3); 4) $30 \mathrm{~cm} \times 30 \mathrm{~cm}$ (T4); and 5) $35 \mathrm{~cm} \times 35 \mathrm{~cm}$ (T5). The experiment was set in a Randomized Complete Block Design (RCBD) and transplanted with uniform age of 12 days old seedlings in all treatments. The rice variety tested was TXD 306 Super SARO which was recommended by the Ministry of Agriculture for flooded rice in central and eastern Tanzania. Data was collected throughout the two growing seasons (Masika and Vuli) of 2013 and 2014. Data collected include biomass at vegetative, flowering and harvesting stages, total number of tillers per hill, number of productive tillers per hill, number of grains per panicle and rice grain yield at the end of the season. Data was analyzed using SAS software version 9.1. Results have shown that transplanting spacing of $25 \mathrm{~cm} \times 25 \mathrm{~cm}, 30 \mathrm{~cm} \times 30 \mathrm{~cm}$ and $35 \mathrm{~cm} \times 35 \mathrm{~cm}$ has significantly performed better than rice transplanted at $15 \mathrm{~cm} \times 15 \mathrm{~cm}$ and $20 \mathrm{~cm} \times 20 \mathrm{~cm}$. For the higher performing treatments, $25 \mathrm{~cm} \times 25 \mathrm{~cm}$ has performed much higher than the rest. It is therefore recommended that for rice variety TXD 306 Super SARO under SRI practice in areas with soil conditions similar to Mkindo area in Morogoro Region, the optimum transplanting spacing that gives maximum yield is $25 \times 25 \mathrm{~cm}$.

\section{Keywords}

SRI, Transplanting Spacing, Biomass, Tillers, Productive Tillers, Hill, Treatment, Yield

\footnotetext{
${ }^{*}$ Corresponding author.
}

How to cite this paper: Reuben, P., Kahimba, F.C., Katambara, Z., Mahoo, H.F., Mbungu, W., Mhenga, F., Nyarubamba, A. and Maugo, M. (2016) Optimizing Plant Spacing under the Systems of Rice Intensification (SRI). Agricultural Sciences, 7, 270-278. http://dx.doi.org/10.4236/as.2016.74026 


\section{Introduction}

Introduction of the Systems of Rice Intensification (SRI) practice in Madagascar in the 1980s created the beginning of new era of increasing rice production and productivity per unit area of up to $50 \%-200 \%$ [1] using less production inputs such as seed, organic/inorganic fertilizer, water, and pumping costs [2] [3]. Other advantages are decrease in amount of irrigation water by $25 \%$ to $50 \%$ [4], less investment capital, which favors small holder farmers, and higher returns at the end of the season [3] [5]. Due to its performance, SRI has been a common system in many areas of the world, though it has been performing differently in different areas, creating the need of testing SRI parameters before adoption in a given locality.

In African countries SRI has also been reported to perform better as compared to conventional rice cultivation. The SRI practice has shown to save irrigation water by $24 \%$, increase land productivity by $71 \%$ and water productivity by $90 \%$ [5]. In East African countries, SRI has also been reported to have good performance as compared to conventional rice irrigation systems. This is evident in studies conducted in Kenya [5] and Tanzania [6]. In Tanzania the system was introduced by Kilombero company limited in year 2006 [6]. It was later spread into different areas of the country. However, optimum values of different parameters under SRI growing practice for specific areas are still not known thus necessitating the need for conducting experiments to optimize the parameters and hence increase SRI productivity.

The benefits of SRI such as increasing rice yield using less input such as seeds, irrigation water, using locally available manure [7], but also inorganic fertilizer [8] and reduced labor by introduction of mechanical weeders for weeding have created the need for testing different SRI parameters differently to investigate how they contribute to increasing yield. The important SRI parameters for increasing yield, that have been reported by different studies, are transplanting spacing between rice hills, transplanting as younger seedlings as possible, transplanting one seedlings per rice hill, application of organic fertilizer whenever possible and alternate wetting and drying irrigation schedule [6] [9] [10].

Optimum transplanting spacing has been reported to be an important parameter in SRI systems for harvesting higher possible grain yield [10]-[12]. The plant spacing in rice has effects on plant population, biomass, tillering of rice hills, productive tillers per hill, and number of grains per panicle [12]. All these are important indicators of rice yield at the end of the season. However, the optimum transplanting spacing have shown to be different in different areas of the world depending on local conditions, thus creating the need to test transplanting spacing that will give maximum yield in local conditions before further spreading of SRI in Tanzania.

The study was conducted to investigate the optimum transplanting spacing at Mkindo village [6], which had three treatments: $25 \mathrm{~cm} \times 25 \mathrm{~cm}, 30 \mathrm{~cm} \times 30 \mathrm{~cm}$ and $35 \mathrm{~cm} \times 35 \mathrm{~cm}$ reported that transplanting spacing of 25 $\mathrm{cm} \times 25 \mathrm{~cm}$ was optimum. In the recommendation, the study argued on the importance of testing less spacing to see whether there might be higher returns as compared to the recommended spacing.

Based on his recommendations, experiments were conducted in 2013 and 2014 with five spacing treatments of $15 \mathrm{~cm} \times 15 \mathrm{~cm}, 20 \mathrm{~cm} \times 20 \mathrm{~cm}, 25 \mathrm{~cm} \times 25 \mathrm{~cm}, 30 \mathrm{~cm} \times 30 \mathrm{~cm}$ and $35 \mathrm{~cm} \times 35 \mathrm{~cm}$ so as to test the hypothesis that there were higher yields of rice grain at lower spacing. All treatments were uniformly irrigated at alternate wetting and drying procedures with uniform management and uniform application of fertilizer and other agronomic practices.

\section{Methodology}

\subsection{Description of the Study Area}

Mkindo Irrigation Scheme is located in Mkindo village in Hembeti Ward, Mvomero District, Morogoro Region in Tanzania. Geographically, the Mkindo Irrigation Scheme lies between latitude $6^{\circ} 16^{\prime}$ and $6^{\circ} 18^{\prime}$ South and longitude $37^{\circ} 32^{\prime}$ and $37^{\circ} 36^{\prime}$ East (Figure 1). The altitude ranges from 345 metres to slightly above 365 metres amsl. The study area is characterized by an average annual temperature of $24.4^{\circ} \mathrm{C}$, with a minimum of $15.1^{\circ} \mathrm{C}$ in July and a maximum of $32.1^{\circ} \mathrm{C}$ in February. The mean relative humidity is $67.5 \%$. The area has bimodal rainfall regime with short rains from October to December (OND) and long rains from March to May (MAM). The average total rainfall per year is between $1200 \mathrm{~mm}$ to $1500 \mathrm{~mm}$ [13].

The Mkindo rice irrigation scheme has a well-organized irrigation infrastructure (headwork on Mkindo Perennial River, partly lined main canal, and unlined secondary and tertiary canals, and drainage canals). The scheme was constructed in the period between 1980 and 1983. The scheme started producing rice in 1985 with 


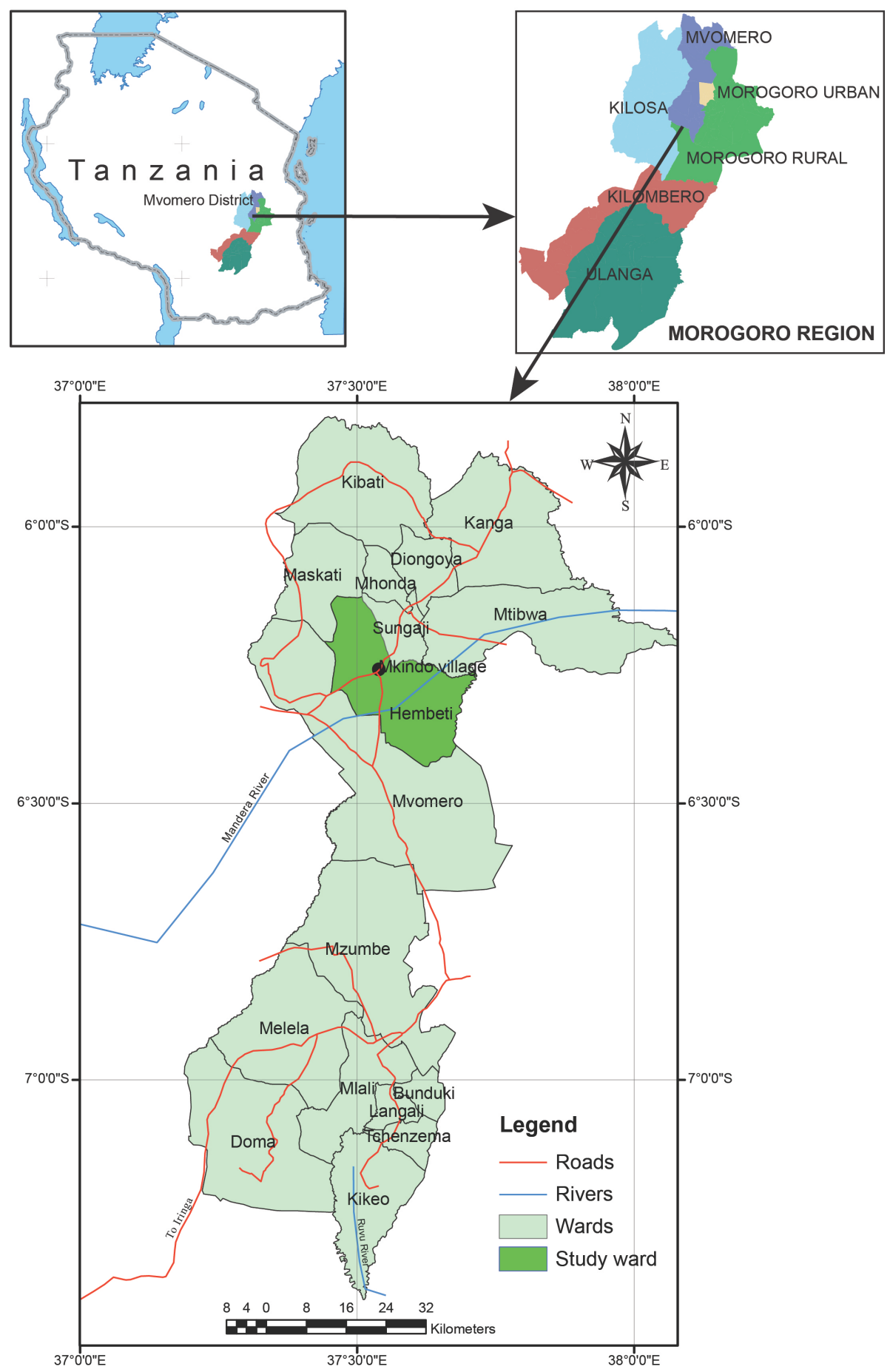

Figure 1. Location of the study area [14].

only 17 ha under cultivation. Currently the scheme serves about 100 ha (250 acres) and a near future expansion is about 620 ha downstream of the current cultivated area.

\subsection{Investigation of Rice Transplanting Spacing}

The experiment to investigate rice transplanting spacing was conducted in two cropping seasons of year 2013 and 2014. In each season data was collected at different growth stages. Information collected include biomass, 
number of tillers per hill, number of productive tillers per hill, number of grains per panicle and grain yields at the end of the season. Methodologies for each parameter are discussed below.

\subsubsection{Experimental Set up and Design}

The experimental site for rice transplanting spacing was located in the Mkindo irrigation scheme, which has well-lined primary canals and good water flow throughout the season. The rice variety tested was TXD 306 Super SARO, which is recommended by the ministry of Agriculture. The source of irrigation water for the scheme is Mkindo River flowing from the forested Nguru Mountains making it a perennial River. The experimental field size of $63.5 \mathrm{~m} \times 6.7 \mathrm{~m}$ was used (Figure 2). The block was divided into 5 treatments replicated 3 times each to form 15 sub-plots of $3.9 \mathrm{~m} \times 6.7 \mathrm{~m}$. The five treatments tested were as follows: (1) T1 = rice seedling transplanted at $15 \mathrm{~cm} \times 15 \mathrm{~cm} \mathrm{(2)} \mathrm{T2} \mathrm{=} \mathrm{rice} \mathrm{seedling} \mathrm{transplanted} \mathrm{at} 20 \mathrm{~cm} \times 20 \mathrm{~cm}$ (3) $\mathrm{T} 3=$ rice seedling transplanted at $25 \mathrm{~cm} \times 25 \mathrm{~cm}(4) \mathrm{T} 4=$ rice seedling transplanted at $30 \mathrm{~cm} \times 30 \mathrm{~cm}(5) \mathrm{T} 5=$ rice seedling transplanted at $35 \mathrm{~cm} \times 35 \mathrm{~cm}$ (Figure 2). All treatments were transplanted using seedlings of 12 days old. The field trial experiments for each season were set in a randomized complete block design (RCBD). The general field layout is as shown in Figure 2.

Initially, field cultivation and later pulverization were conducted using a power tiller tractor. The field was then leveled by hand hoe. For transplanting in different spacing, five wooden space markers of different spacing were constructed for marking transplanting points/grids. The space markers had spacing of $15 \mathrm{~cm} \times 15 \mathrm{~cm}, 20$ $\mathrm{cm} \times 20 \mathrm{~cm}, 25 \mathrm{~cm} \times 25 \mathrm{~cm}, 30 \mathrm{~cm} \times 30 \mathrm{~cm}$ and $35 \mathrm{~cm} \times 35 \mathrm{~cm}$, respectively. Seedlings were then picked from the seedling site using baskets and buckets and then transplanted one seedling per rice hill. Weeding and other agronomic activities were uniformly applied throughout the growing season.

\subsubsection{Biomass}

Biomass sampling was conducted at vegetative (60 - 65 days from transplanting), flowering (85 - 90 days from transplanting), and maturity (110 - 115 days from transplanting) stages during the growing season. Sampling area of $1 \mathrm{~m}^{2}$ was measured using tape measure and cutting of above ground biomass was conducted using knives and sickles. Samples were then packed in the labeled bags and brought to laboratory for analysis.

Biomass was further chopped into small pieces (in the laboratory), weighed and then recorded on data recording sheet as a fresh weight biomass. Sub-sample biomass was then taken from each weighed fresh biomass bag, reweighed, put in another bag, labeled and then put in the oven for drying. The oven was set at a temperature of $70^{\circ} \mathrm{C}$ for 3 consecutive days. Samples were removed from the oven, re-weighed and recorded for analysis. The following formula [14] was used to calculate the crop biomass per hectare:

$$
\text { Net gross weight of fresh biomass per square metre = Gross weight }- \text { weight of bag }
$$

Net sub sample fresh weight $=$ Fresh sub sample weight - weight of bag

Gross weight of dry biomass per square metre $=\frac{\text { Dry sub sample weight }}{\text { Fresh sub sample weight }} \times$ Gross fresh weight

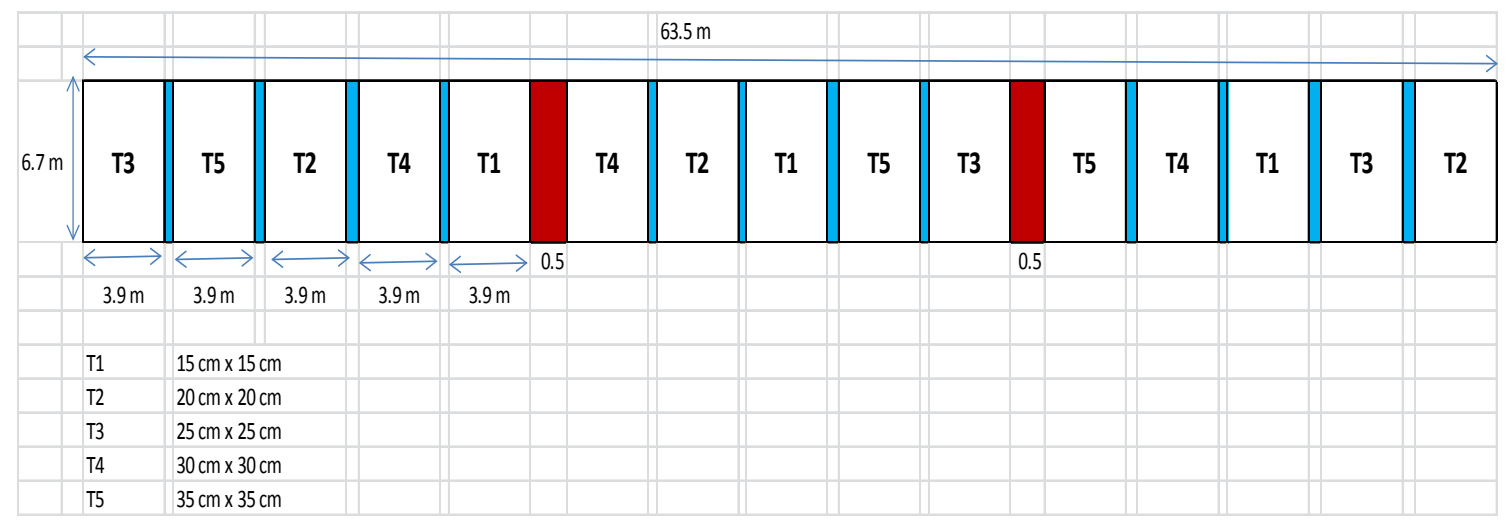

Figure 2. Transplanting spacing experiment layout. 


\subsubsection{Tillers, Productive Tillers per Hill and Number of Grains per Panicle}

The estimation of number of tillers and productive tillers per hill was conducted at crop maturity stages. From each plot, 5 hills marked a few days after transplanting for data collection were used for estimation of number of total and productive tillers per hill. Counting of tillers was done by hand and recording was done using data recording sheet for analysis. The number of grains per panicle was counted at crop maturity. In each subplot 5 tillers monitoring hills were investigated. One panicle was chosen at random and counted by hand and then recorded for analysis.

\subsubsection{Yield}

Rice grain yield was estimated at maturity stage (110 - 120 days after transplanting). Samples for analysis were harvested at an area of $1 \mathrm{~m}^{2}$. Harvesting areas were measured by a tape measure. Rice panicles were then cut using knives and sickles and put into the labelled bag for further processing in the laboratory. At the laboratory rice seeds were separated from straws, weighed using measuring scale and then recorded on data recording sheet as a fresh weight grains. The sub-sample grains was taken from each bag, reweighed again, labelled and then put in the oven which was set at a temperature of $70^{\circ} \mathrm{C}$ and then oven dried for 3 consecutive days. Re-weighing of the dry grains was conducted after three to five days. Data was then recorded for analysis. The following formula was used to calculate the grain yield per hectare [14].

$$
\begin{aligned}
& \text { Net gross weight of fresh biomass per square metre }=\text { Gross weight }- \text { weight of bag } \\
& \text { Sub sample fresh weight }=\text { Fresh sub sample weight }(g) \text {-weight of the bag }(g) \\
& \text { Weight of dry sub sample }=\text { dry sub sample weight }- \text { weight of the bag } \\
& \text { Gross weight per square metre }=\frac{\text { Dry sub sample weight }}{\text { Fresh sub sample weight }} \times \text { Gross fresh weight } \\
& \text { Gross weight per hectare }=\text { Gross weight per square metre } \times 10,000
\end{aligned}
$$

\subsection{Data Analysis}

Quantitative data were analyzed using a statistical analysis software SAS version 9.1 (SAS Inc year) following General Linear Model (GLM) procedures [12] [14]-[16]. To find variation between treatments, Analysis of variance (ANOVA) of crop yield indicators such as biomass; total number of tillers and productive tillers per hill; and number of grains per panicle were conducted. The $t$ test Least Square Difference (LSD) was also conducted so as to control type I comparison-wise error rate of the treatments whenever significance difference between treatments occur.

\section{Results and Discussion}

\subsection{Biomass}

The crop dry biomass was investigated in vegetative, flowering and maturity stages of crop cycle. The biomass was 3.7, 4.4, 3.4, 2.2 and 4.3 tons per hectare for spacing $15 \mathrm{~cm} \times 15 \mathrm{~cm}, 20 \mathrm{~cm} \times 20 \mathrm{~cm}, 25 \mathrm{~cm} \times 25 \mathrm{~cm}, 30 \mathrm{~cm}$ $\times 30 \mathrm{~cm}$, and $35 \mathrm{~cm} \times 35 \mathrm{~cm}$ treatments, respectively (Figure 3). At flowering stage the biomass in tons per hectare increased to 11.3, 8.8, 11.7, 7.9 and 8.2. At crop maturity stage the biomass was 7.8, 5.3, 7.1, 5.0 and 5.1 tons per hectare.

At vegetative stage ( $p=0.05$ ), the results have shown that, there was no significance difference in biomass yield between treatments. At flowering stage, results have shown that rice transplanted at spacing $15 \mathrm{~cm} \times 15$ $\mathrm{cm}$ and $25 \mathrm{~cm} \times 25 \mathrm{~cm}$ were significantly higher in biomass yield as compared to the rest with later treatment perform slightly higher. In other words spacing of $20 \mathrm{~cm} \times 20 \mathrm{~cm}, 30 \mathrm{~cm} \times 30 \mathrm{~cm}$ and $35 \mathrm{~cm} \times 35 \mathrm{~cm}(\mathrm{p}=0.05)$ had no significant different in biomass yield. At late stages, the mean biomass yields of spacing $15 \mathrm{~cm} \times 15 \mathrm{~cm}$ and $25 \mathrm{~cm} \times 25 \mathrm{~cm}$ have shown to have significant better performance $(\mathrm{p}<0.05)$ as compared to rest of treatments. This significance comparison was conducted using t test LSD procedures for the purpose of identifying 




Figure 3. Rice biomass at different stages of crop growth.

the strength of certain treatments over the rest in terms of yields and controlling type I error. Generally, the results have favored lower spacing to be much productive in terms of biomass due to its high density of crops.

\subsection{Comparison of Total Number of Tillers per Hill and Productive Tillers per Hill}

The total number of tillers and productive tillers per hill was estimated during maturity stage of rice growth (Figure 4). The average total number of tillers per hill was 15.3, 21.3, 28, 31.3 and 35.7 for spacing $15 \mathrm{~cm} \times 15$ $\mathrm{cm}, 20 \mathrm{~cm} \times 20 \mathrm{~cm}, 25 \mathrm{~cm} \times 25 \mathrm{~cm}, 30 \mathrm{~cm} \times 30 \mathrm{~cm}$ and $35 \mathrm{~cm} \times 35 \mathrm{~cm}$, respectively. The estimated number of productive tillers per hill for these treatments was 15, 20, 24, 24.3 and 34 respectively. The results have shown that at smaller spacing between rice hills, almost all tillers were productive whereas at higher spacing some of the tillers were not productive though higher spacing has higher number of tillers/ productive tillers per hill.

The results show that there was a significant difference $(\mathrm{p}<0.05)$ in number of productive tillers per rice hill in different treatments. Spacing of $35 \mathrm{~cm} \times 35 \mathrm{~cm}, 30 \mathrm{~cm} \times 30 \mathrm{~cm}$ and $25 \mathrm{~cm} \times 25 \mathrm{~cm}$ yielded higher as compared to $15 \mathrm{~cm} \times 15 \mathrm{~cm}$ and $20 \mathrm{~cm} \times 20 \mathrm{~cm}$. Among treatments, $35 \mathrm{~cm} \times 35 \mathrm{~cm}$ had relatively higher number of productive tillers per hill than $30 \mathrm{~cm} \times 30 \mathrm{~cm}$ and $25 \mathrm{~cm} \times 25 \mathrm{~cm}$. This is because at higher spacing, there is no competition of nutrients, air and light, thus creating a better environment for crop growth.

\subsection{Number of Grains per Panicle}

The analysis was carried out to find whether there is a significant difference in the number of grains per panicle between the five treatments. The results have shown that spacing of $25 \mathrm{~cm} \times 25 \mathrm{~cm}, 30 \mathrm{~cm} \times 30 \mathrm{~cm}$ and $35 \mathrm{~cm} \times$ $35 \mathrm{~cm}$ treatments performed significantly higher $(\mathrm{p}<0.05)$ as compared to $15 \mathrm{~cm} \times 15 \mathrm{~cm}$ and $20 \mathrm{~cm} \times 20 \mathrm{~cm}$.

The mean number of grains per panicle was found to be 143.7, 136.7, 217, 190.3 and 205.7 for the spacing of $15 \mathrm{~cm} \times 15 \mathrm{~cm}, 20 \mathrm{~cm} \times 20 \mathrm{~cm}, 25 \mathrm{~cm} \times 25 \mathrm{~cm}, 30 \mathrm{~cm} \times 30 \mathrm{~cm}$ and $35 \mathrm{~cm} \times 35 \mathrm{~cm}$ treatments, respectively (Figure 5). The trend shows that, the number of grains per panicle increases with spacing. However, the yield at higher spacing might be lower due to less plant density. Generally it can be concluded that, higher spacing had better performance in terms of number grains per panicle as compared to lower spacing due to less competition of nutrients, air and light creating better environment for crop growth.

\subsection{Yield}

The yield for the five treatments was also investigated at the end of each season. At 0.05 level of significance, the analysis has shown evidence that there was a significant difference in rice yields between the treatments. Spacing of $25 \mathrm{~cm} \times 25 \mathrm{~cm}, 30 \mathrm{~cm} \times 30 \mathrm{~cm}$ and $35 \mathrm{~cm} \times 35 \mathrm{~cm}$ had no significant difference in grain yield $(\mathrm{p}<$ 0.05), though the yield was slightly higher on spacing $25 \mathrm{~cm} \times 25 \mathrm{~cm}$ as compared to the rest. Yield difference was more significant on spacing $25 \mathrm{~cm} \times 25 \mathrm{~cm}, 30 \mathrm{~cm} \times 30 \mathrm{~cm}$ and $35 \mathrm{~cm} \times 35 \mathrm{~cm}$ when compared to spacings of $15 \mathrm{~cm} \times 15 \mathrm{~cm}$ and $20 \mathrm{~cm} \times 20 \mathrm{~cm}(\mathrm{p}<0.05)$. Furthermore, yields on smaller spacings $(15 \mathrm{~cm} \times 15 \mathrm{~cm}$ and $20 \mathrm{~cm} \times 20 \mathrm{~cm}$ ) were not significantly different. The rice yield was 4.41, 5.13, 7.57, 6.78 and 6.5 tones/ha for 


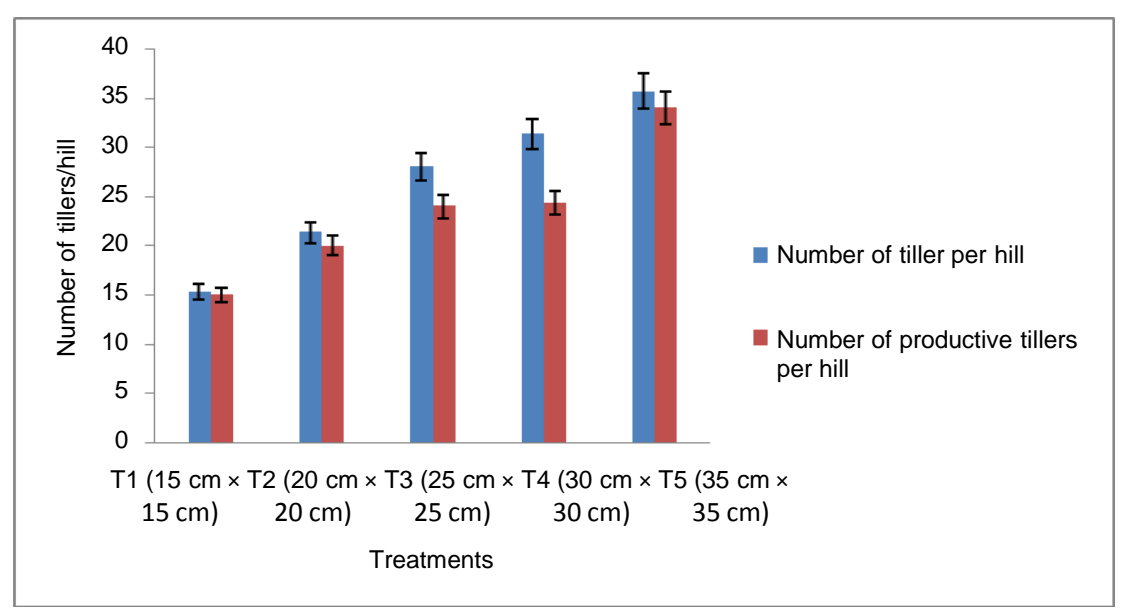

Figure 4. Number of productive and non-productive tillers per hill.

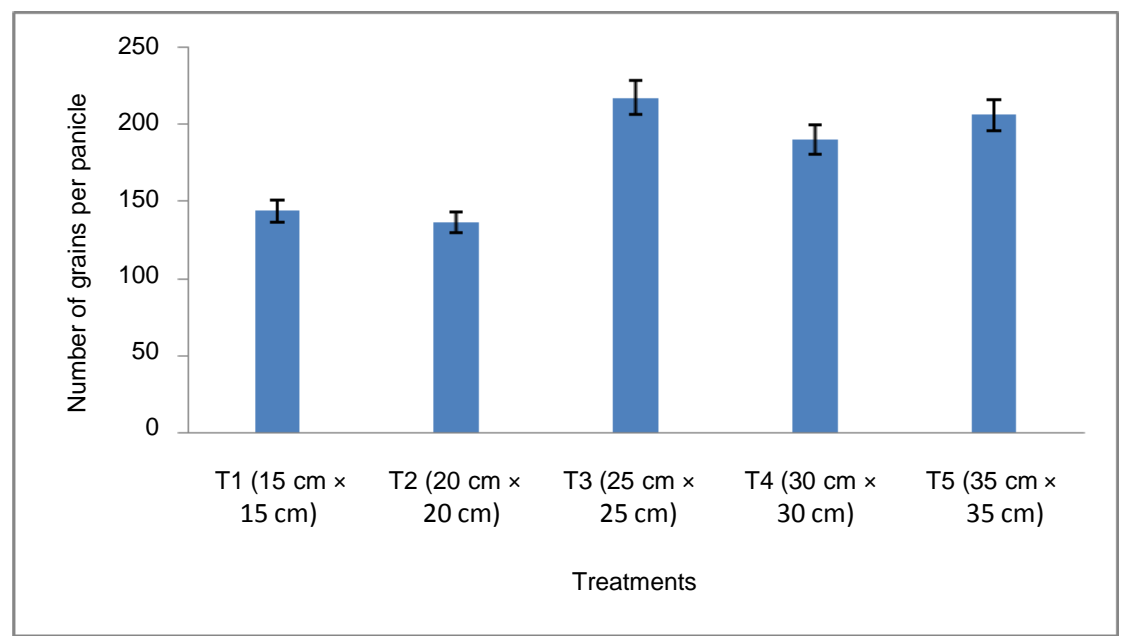

Figure 5. Number of grain per panicle at different spacing.

spacing of $15 \mathrm{~cm} \times 15 \mathrm{~cm}, 20 \mathrm{~cm} \times 20 \mathrm{~cm}, 25 \mathrm{~cm} \times 25 \mathrm{~cm}, 30 \mathrm{~cm} \times 30 \mathrm{~cm}$ and $35 \mathrm{~cm} \times 35 \mathrm{~cm}$ space, respectively (Figure 6).

It is therefore evidently concluded that, rice transplanted at spacing $25 \mathrm{~cm} \times 25 \mathrm{~cm}$ yields higher as compared to the rest treatments followed by $30 \mathrm{~cm} \times 30 \mathrm{~cm}$ and $35 \mathrm{~cm} \times 35 \mathrm{~cm}$. This is due to the fact that, higher spacing between rice hill produce many grains per panicle and tillers.

\section{Conclusions}

This experiment was conducted to investigate the optimum transplanting spacing between rice hills for the purpose of maximizing rice grain yield under the system of rice intensification (SRI). This was conducted by optimizing yield indicators throughout the growing season such as biomass, number of tillers per hill leading into productive tillers and number of grains per panicle. The treatments were 1) T1 = rice seedling transplanted at 15 $\mathrm{cm} \times 15 \mathrm{~cm}$; 2) T2 = rice seedling transplanted at $20 \mathrm{~cm} \times 20 \mathrm{~cm}$; 3) T3 = rice seedling transplanted at $25 \mathrm{~cm} \times$ $25 \mathrm{~cm}$; 4) T4 = rice seedling transplanted at $30 \mathrm{~cm} \times 30 \mathrm{~cm}$; ) T5 = rice seedling transplanted at $35 \mathrm{~cm} \times 35 \mathrm{~cm}$.

At flowering stage, the results have shown that, rice transplanted at spacing $15 \mathrm{~cm} \times 15 \mathrm{~cm}$ and $25 \mathrm{~cm} \times 25$ $\mathrm{cm}$ was significantly higher in biomass yield as compared to the rest with $25 \mathrm{~cm} \times 25 \mathrm{~cm}$ treatment perform slightly higher. The results have shown no significant difference in rice biomass yield at vegetative stage $(\mathrm{p}<$ 0.05). At late stages (maturity), the means biomass yields of spacing $15 \mathrm{~cm} \times 15 \mathrm{~cm}$ and $25 \mathrm{~cm} \times 25 \mathrm{~cm}$ have shown to have significant better performance $(\mathrm{p}<0.05)$ as compared to rest of treatments. 




Figure 6. Rice yield at different transplanting spacing.

The number of tillers per hill was also shown to be significant difference $(\mathrm{p}<0.05)$ in different treatments with spacing of $25 \mathrm{~cm} \times 25 \mathrm{~cm}, 30 \mathrm{~cm} \times 30 \mathrm{~cm}$ and $35 \mathrm{~cm} \times 35 \mathrm{~cm}$ performed better as compared to $15 \mathrm{~cm} \times 15$ $\mathrm{cm}$ and $20 \mathrm{~cm} \times 20 \mathrm{~cm}$. In terms of number of grain per panicle, the results have shown that spacing $25 \mathrm{~cm} \times 25$ $\mathrm{cm}, 30 \mathrm{~cm} \times 30 \mathrm{~cm}$ and $35 \mathrm{~cm} \times 35 \mathrm{~cm}$ treatments performed significantly higher $(\mathrm{p}<0.05)$ as compared to 15 $\mathrm{cm} \times 15 \mathrm{~cm}$ and $20 \mathrm{~cm} \times 20 \mathrm{~cm}$. All these have led into significant higher yields of treatments with spacing 25 $\mathrm{cm} \times 25 \mathrm{~cm}, 30 \mathrm{~cm} \times 30 \mathrm{~cm}$ and $35 \mathrm{~cm} \times 35 \mathrm{~cm}$ as compared to spacing $15 \mathrm{~cm} \times 15 \mathrm{~cm}$ and $20 \mathrm{~cm} \times 20 \mathrm{~cm}(\mathrm{p}<$ 0.05 ) with slight higher performance on spacing $25 \mathrm{~cm} \times 25 \mathrm{~cm}$.

It is therefore concluded that under the SRI practice rice transplanted at spacing $25 \mathrm{~cm} \times 25 \mathrm{~cm}$ yields higher as compared to the rest treatments followed by $30 \mathrm{~cm} \times 30 \mathrm{~cm}$ and $35 \mathrm{~cm} \times 35 \mathrm{~cm}$ with no significant difference between them $(p>0.05)$. This is due to the fact that higher spacing between rice hills have favorable environment for plant growth as compared to lower spacing.

\section{Acknowledgements}

We would like to thank the Tanzania Commission of Science and Technology (COSTECH) for the financial support, which enabled the implementation of the findings. Thanks also go to the following institutions for their collaboration during conducting the study: Sokoine University of Agriculture (SUA), Ministry of Agriculture, Food Security and Cooperatives (MAFC), Mbeya University of Science and Technology (MUST), SUA Pest Management Centre (SPMC), and the Mkindo Farmers Training Centre (FTC). Special thanks also give to the Mkindo Village Government and farmers who tirelessly worked with the researchers in achieving the project objectives.

\section{References}

[1] Dobermann, A. (2004) A Critical Assessment of the System of Rice Intensification (SRI). Agricultural Systems, 79, 261-281. http://dx.doi.org/10.1016/S0308-521X(03)00087-8

[2] Stoop, W.A., Uphoff, N. and Kassam, A. (2002) A Review of Agricultural Research Issues Raised by the System of Rice Intensification (SRI) from Madagascar: Opportunities for improving Farming Systems for Resource-Poor Farmers. Agricultural Systems, 71, 249-274. http://dx.doi.org/10.1016/S0308-521X(01)00070-1

[3] Uphoff, N., Kassam, A.H. and Harwood, R. (2011) SRI as a Methodology for Raising Crop and Water Productivity: Productive Adaptations in Rice Agronomy and Irrigation Water Management. Paddy and Water Environment, 9, 3-11. http://dx.doi.org/10.1007/s10333-010-0224-4

[4] Satyanarayana, A., Thiyagarajan, T.M. and Uphoff, N. (2007) Opportunities for Water Saving with Higher Yield from the System of Rice Intensification. Irrigation Science, 25, 99-115. http://dx.doi.org/10.1007/s00271-006-0038-8

[5] Nyamai, M., Mati, B.M., Home, P.G., Odongo, B., Wanjogu, R. and Thuranira, E.G. (2012) Improving Land and Water Productivity in Basin Rice Cultivation in Kenya through System of Rice Intensification (SRI). Agricultural Engi- 
neering International: CIGR Journal, 14, Manuscript No. 2094.

[6] Katambara, Z., Kahimba, F., Mahoo, H., Mbungu, W., Mhenga, F., Reuben, P., Maugo, M. and Nyarubamba, M. (2013) Adopting the System of Rice Intensification (SRI) in Tanzania: A Review. Journal of Agricultural Sciences, 4, 369375. http://dx.doi.org/10.4236/as.2013.48053

[7] Wu, W., Ma. B.L. and Uphoff, N. (2015) A Review of System of Rice Intensification in China. Plant and Soil, 393, 361-381. http://dx.doi.org/10.1007/s11104-015-2440-6

[8] Chapagain, T., Riseman, A. and Yamaji, E. (2011) Assessment of System of Rice Intensification (SRI) and Conventional Practices under Organic and Inorganic Management in Japan. Rice Science, 18, 311-320. http://dx.doi.org/10.1016/s1672-6308(12)60010-9

[9] Debal, D., Lässig, J. and Kloft, M. (2012) A Critical Assessment of the Importance of Seedling Age in the System of Rice Intensification (SRI) in Eastern India. Experimental Agriculture, 48, 326-346.

[10] Thakur, A.K., Rath, S., Roychowdhury, S. and Uphoff, N. (2010) Comparative Performance of Rice with System of Rice Intensification (SRI) and Conventional Management Using Different Plant Spacings. Journal of Agronomy and Crop Sciences, 196, 146-159. http://dx.doi.org/10.1111/j.1439-037X.2009.00406.X

[11] Hasanuzzaman, M., Nahar, K., Roy, T.S., Rahman, M.L., Hossain, M.Z. and Ahmed, J.U. (2009) Tiller Dynamics and Dry Matter Production of Transplanted Rice as Affected by Plant Spacing and Number of Seedling per Hill. Academic Journal of Plant Sciences, 2, 162-168.

[12] Menete, M.Z.L., Van Es, R.M.L., Brito, S.D., DeGloria, H.M. and Famba, S. (2008) Evaluation of the System of Rice Intensification (SRI) Component Practices and Their Synergies on Salt-Affected Soils. Field Crops Research, 109, $34-$ 44. http://dx.doi.org/10.1016/j.fcr.2008.06.003

[13] Bracebridge, C. (2006) Mkindo Forest Reserve: Forest Disturbance Report. Report for Tanzania Forest Conservation Group and Participatory Environmental Management Programme, Dar es Salaam.

[14] Reuben, P., Katambara, Z., Kahimba, F., Mahoo, H., Mbungu, W., Mhenga, F., Nyarubamba, A. and Maugo, M. (2016) Influence of Transplanting Age on Paddy Yield under the System of Rice Intensification. Agricultural Sciences, 7, 154-163. http://dx.doi.org/10.4236/as.2016.73015

[15] Ginigaddara, G.A.S. and Ranamukhaarachchi, S.L. (2011) Study of Age of Seedlings at Transplanting on Growth Dynamics and Yield of Rice under Alternating Flooding and Suspension of Irrigation of Water Management. Recent Research in Science and Technology, 3, 76-88.

[16] Krupnik, T.J., Shennan, C., Settle, W.H., Demont, M., Ndiaye, A. and Rodenburg, J. (2012) Improving Irrigated Rice Production in the Senegal River Valley through Experiential Learning and Innovation. Agricultural Systems, 109, 101112. http://dx.doi.org/10.1016/j.agsy.2012.01.008 